\title{
The relation between blood lead and mercury levels and chronic neurological diseases in children
}

\author{
Gürcan Dikme, Ahmet Arvas, Emel Gür \\ Istanbul University, Cerrahpaşa Medical Faculty, Department of Pediatrics, Division of Social Pediatrics, Istanbul, Turkey
}

\section{Summary}

Aim: The aim of our study was to investigate the relation between lead and mercury exposure and some chronic neurodevelopmental diseases in children.

Material and Method: In the Departments of Pediatric Neurology and Pediatric Psychiatry clinics, children diagnosed with motor-mental retardation, epilepsy, attention deficit/hyperactivity disorder and autism were included in the study as the study group (39 boys and 20 girls). Age and sex matched healthy children were used as controls. Blood lead and mercury levels were measured using the atomic absorption spectrophotometry method. The possible effect of environmental factors that could cause exposure to heavy metals (such as vaccination, fish consumption and the number of dental fillings the mother had) were also considered.

Results: The average age was 7.66 years and 7.68 years in the study and the control groups, respectively. The average lead level in the blood was $1.91 \mu \mathrm{g} / \mathrm{dl}$ in the study group, $2.19 \mu \mathrm{g} / \mathrm{dl}$ in the control group. The average mercury level in the blood was $0.84 \mu \mathrm{g} / \mathrm{L}$ in the study group and $0.99 \mu \mathrm{g} / \mathrm{L}$ in the control group. No significant difference was found between the study and control groups in terms of blood mercury and lead levels. When the relation of vaccination, the frequency of fish consumption and the number of dental fillings in the mother with blood lead and mercury levels was evaluated, no significant difference was found between the study and control groups. Conclusions: Our study shows that the heavy metal levels of children with chronic neurodevelopmental diseases are not different from those of healthy children. Yet this conclusion does not lower the significance of enviromental heavy metal hazard on human health. (Turk Arch Ped 2013; 48: 221-225)

Key words: Blood lead level, blood mercury level, chronic neurodevelopmental disease, environmental exposure

\section{Introduction}

Despite current rapid advances in medicine, no marked reduction has occured in the prevalence of childhood neurological diseases worldwide. Although genetic, congenital, metabolic, environmental and socioeconomical risk factors are involved in development of childhood neurodevelopmental diseases, no cause can be demonstrated in an importan part of these diseases $(1,2)$.

The relation of heavy metal intoxications including lead and mercury with attention deficit/hyperactivity disorder (ADHD) and autism spectrum disease (ASD) has drawn the attention of investigators for a long time $(3,4)$. In various studies, the blood mercury and lead levels in children with a diagnosis of ADHD have been shown to be higher compared to healthy children $(5,6)$. In a study performed by Bradstreet et al. (7), mercury levels were found to be significantly higher in DMSA-induced urine samples in children with autism compared to healthy controls. Similar results were obtained in another study (8).

The aim of this study was to demonstrate if there was a relation between some chronic childhood neurodevelopmental diseases and blood lead and mercury levels and evaluate the findings together with the studies performed.

\section{Material and Method}

Children with a diagnosis of motor-mental reatardation (MMR), epilepsy, ADHD and autism followed up mutually in the outpatient clinics of İstanbul University Medical Faculty Divisions of Pediatric Neurology and Pediatric Psychiatry between June 2010 and March 2011 constituted the patient group (a total of 59 children; 39 male, 20 female). 
Age and gender-matched 59 healthy children constituted the control group. The diagnoses of autism and ADHD were made according to the DSM-IV diagnositc criteria (9). Prenatal and postnatal histories of the children with MMR were taken. No evidence of intrauterine infection or perinatal asphyxia was found in the patients. There was no phenotypical characteristic or genetic syndrome definition in the patients. The Stanford-Binet test was used to evaluate gross and fine motor skills and WISC-R (Wechsler Intelligence Scale for Children) was used to evaluate intelligence. Metabolic screening tests, thyroid function tests, complete blood count, blood biochemical tests, complete urinalysis and cranial imaging (magnetic resonance-MR) were performed in all patients. As a result of the tests performed no diagnosis could be made in the patients and they were considered as idiopathic MMR. The patients mostly had severe or moderate MMR characteristics. The patients with epilepsy had recurrent epileptic seizures without any stimulating factor, their EEGs were compatible with epilepsy, they had no neurological sequela and no pathology which could lead to epilepsy could be found on their cranial MRls. The patients had differrent seizure types. The control group was selected from the children who were being followed up in the Outpatient Clinic of Well Child and presented to İstanbul University

\begin{tabular}{|c|c|c|c|}
\hline & $\begin{array}{c}\text { Age } \\
\text { (years) }\end{array}$ & $\begin{array}{l}\text { Gender } \\
\text { (M/F- \%) }\end{array}$ & Mean $\pm S D$ \\
\hline $\begin{array}{l}\text { Patient group } \\
(n=59)\end{array}$ & $1.6-16$ & $39 / 20(66.1-33.9)$ & $7.66 \pm 4.08$ \\
\hline ADHD (n/\%) & $17(28.8)$ & & \\
\hline Autism (n/\%) & $15(25.5)$ & & \\
\hline Epilepsy (n/\%) & $14(23.7)$ & & \\
\hline $\begin{array}{l}\text { Control group } \\
(n=59)\end{array}$ & $1.6-16$ & $39 / 20(66.1-33.9)$ & $7.68 \pm 4.09$ \\
\hline Total & $1.6-16$ & $78 / 40(66.1-33.9)$ & $7.66 \pm 4.06$ \\
\hline
\end{tabular}

ADHD: Attention deficit/Hyperactivity disorder

MMR: Motor-mental retardation

Mean \pm SD: Mean Standard deviation
Cerrahpaşa Medical Faculty Pediatric Outpatient Clinic because of upper respiratory tract infection, who were born at term, who had normal neuromotor development and who had no chronic disease. Venous blood samples were taken from the children and blood lead and mercury levels were measured using atomic absorption spectrophotometry method. The threshold value for blood lead levels was considered as $10 \mu \mathrm{g} / \mathrm{dL}$. For blood mercury level a value of $>5.8 \mathrm{ug} / \mathrm{L}$ was considered toxic $(10,11,12)$. Vaccinations, monthly fish consumption and the state of maternal dental fillings were interrogated in the specific forms prepared to evaluate lead and mercury exposure in the patient and control groups. In addition, diphteria-whole cell pertussisteatanus (DwBT), haemophilus influeanze type b (Hib), diphteria tetanus (DT) and hepatitis vaccines administered before 2008 according to our national vaccination schedule in this interrogation contain mercury. These vaccines contain $0.025 \mathrm{mg}$ thimerosal (12.5 ethyl mercury) per dose; among the vaccines administered after 2008, only hepatitis $B$ vaccine contains thimerosal. The total amount of mercury in the vaccine doses in the vaccination schedule is $137.5 \mathrm{ug}$ before 2008 and $37.5 \mathrm{ug}$ after 2008. A total mercury exposure of above $425 \mu \mathrm{g}$ in children is toxic according to FDA (Food Drug Administration). The World Health Organization specifies this toxic level as > $501 \mu \mathrm{g}$ in children (13). Four children in the patient group and one child in the control group were not included in the assessment, since they did not receive regular vaccination.

Written approval was obtained from the İstanbul University Cerrahpaşa Medical Faculty Ethics committe of Clinical Investigations (05.04.2011-B03).

The Statistical Package for the Social Sciences (SPSS) 15,0 program was used for statistical analysis. The Kruskal Wallis test was used in descriptive statistical methods (mean, Standard deviation, median, ratio), in comparison of qualitative data and in copmparison of blood lead and mercury variables between the groups. Mann Whitney $U$ test was used in determination of the group which caused the difference and in assessments between two groups and chi-square test was used in comparison of quantitative data. A $p$ value of $<0.05$ was considered significant.

\section{Results}

The mean age was $7.66 \pm 4.08$ years in the children with neurodevelopmental disease (the patient group) and $7.68 \pm 4.09$ in the healthy children (the control group). Both groups included 39 males (66.1\%) and 20 females

Table 2. Blood lead and mercury levels of the patient and control groups

\begin{tabular}{|c|c|c|c|c|c|}
\hline & \multicolumn{2}{|c|}{ Patients group $(n=59)$} & \multicolumn{2}{|c|}{ Control group $(n=59)$} & $p^{*}$ \\
\hline & $\begin{array}{c}\text { The least-the } \\
\text { highest }^{\star \star}\end{array}$ & Mean $\pm S D^{\star \star \star}$ & $\begin{array}{c}\text { The least-the } \\
\text { highest }\end{array}$ & $\begin{array}{l}\text { MeantSS } \\
\text { (median) }\end{array}$ & \\
\hline Lead $(\mu \mathrm{g} / \mathrm{dL})$ & $0.2-6.6$ & $1.91 \pm 0.17(1.70)$ & $0.2-16$ & $2.19 \pm 2.15(1.70)$ & 0.575 \\
\hline Mercury $(\mu \mathrm{g} / \mathrm{L})$ & $0.4-1.7$ & $0.84 \pm 0.22(0.80)$ & $0.5-8.4$ & $0.99 \pm 0.93(0.80)$ & 0.357 \\
\hline
\end{tabular}

*Mann Whitney U Test; **The highest-the least: ${ }^{* \star}$ Mean \pm Standard deviation 
(33.9\%). $28.8 \%$ of the patient group had ADHD, 23.7\% had epilepsy, $22 \%$ had MMR and $25.5 \%$ had autism. The descriptive characteristics of the patient and control groups are shown in Table 1.

The mean blood lead level was $1.91 \pm 0.17 \mu \mathrm{g} / \mathrm{dL}$ in the patient group and $2.19 \pm 2.15 \mu \mathrm{g} / \mathrm{dL}$ in the control group. No significant difference was found between the two groups in terms of lead levels $(p=0.575)$. The blood mercury level was found to be $0.84 \pm 0.22 \mu \mathrm{g} / \mathrm{L}$ in the patient group and $0.99 \pm 0.93 \mu \mathrm{g} / \mathrm{L}$ in the control group. No significant difference was found between the two groups in terms of mercury levels $(p=0.357)$. Table 2 shows the blood lead and mercury levels in the patient and control groups and figure 1 and 2 show the blood lead and mercury levels by age groups. The blood lead and mercury levels were compared between the subgroups in the patient group. According to the Post Hoc Mann Whitney $U$ test which examines the difference between groups a significant difference was found only between the patients autism and epilepsy $(p=0.009)$ and between the patients with ADHD and the patients with epilepsy and MMR $(p=0.002, p=0.026)$ in terms of blood lead levels. No significant difference was found between the subgroups in the patient group in terms of blood mercury levels ( $p>0.05$ in all).

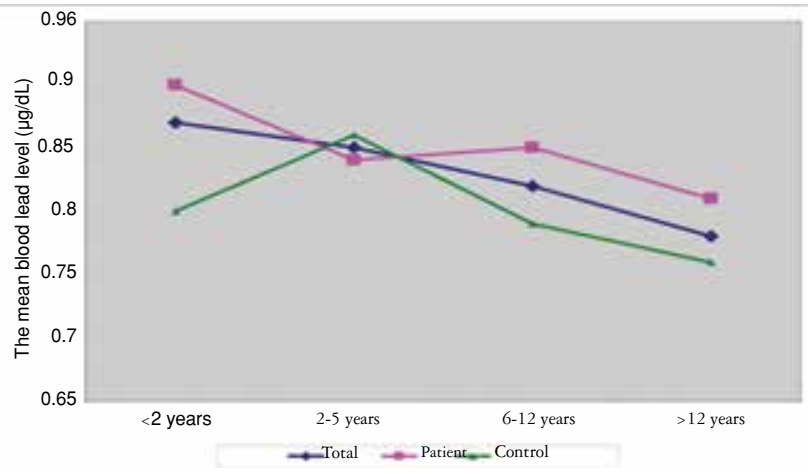

Figure 1. Distribution of blood mercury levels by age

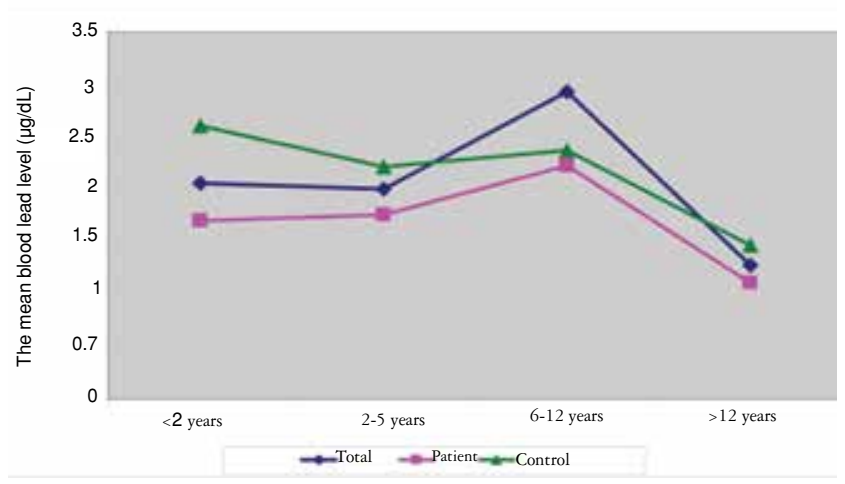

Figure 2. Lead levels by age groups
When the relation of vaccination status, frequency of fish consumption and the number of maternal fillings with blood lead and mercury levels was evaluated, no significant difference was found between the patient and control groups $(p=0.364, p=0.126, p=0.903)$.

In addition, no significant difference was found between the groups in terms of the place of residence, closeness to traffic, line of business of the father (or other family members), drinking water used, use of lead pipe at home, type of heating at home and the number of cigarettes smoked ( $p>0.05$ in all).

\section{Discussion}

In all children included in the study, the blood lead and mercury values were not found to be at toxic levels. In the investigations performed in our country, a reduction has been observed in blood lead levels in children in recent years, with initiation of reduction of lead in gasoline. In a study performed in Ankara, the mean lead level in children was found to be $19,35 \mu \mathrm{g} / \mathrm{dL}$ in 1987 , while it was found to be $3,67 \mu \mathrm{g} / \mathrm{dL}$ in a study performed in the same province in $2003(14,15)$. In studies performed in İstanbul, the mean blood lead level was found to be $5,5 \mu \mathrm{g} / \mathrm{dL}$ in 1995 and 1,5 $\mu \mathrm{g} / \mathrm{dL}$ in 2005. Among various risk factors, lead levels were found to be higher only in regions with intensive traffic (16, 17). Similar findings were observed in USA; the blood lead levels was found to be $15 \mu \mathrm{g} / \mathrm{dL}$ in 1976-1980 in children aged between 1 and 5 years, while they were reduced to $3,6 \mu \mathrm{g} / \mathrm{dL}$ between 1988 and 1991 and to $1,9 \mu \mathrm{g} / \mathrm{dL}$ in 1999 (18). The mean blood lead level in healthy children in our study was similar to the levels found in the studies performed in recent years and published in the literature.

In our country, very few number of studies have been performed to determine the mercury level in biological samples in children and adults. In a study performed by Sağlamtimur et al. (19) in Mersin region, higher than normal mercury levels were found in hair samples of people who consumed deep sea fish. In another study, mercury levels were found to be within normal limits in individuals who had amalgam dental fillings (20). In community screenings, the mean blood mercury level was found to be $0.31 \mu \mathrm{g} / \mathrm{L}$ in Canada, $0.34 \mu \mathrm{g} / \mathrm{L}$ in USA, $0.24 \mu \mathrm{g} / \mathrm{L}$ in Germany and 3,5 $\mu \mathrm{g} / \mathrm{L}$ in China $(12,21,22)$. In our study, the blood mercury level in healthy children was found to be $0,80 \mu \mathrm{g} / \mathrm{L}$ and this value is below the value the threshold value which shows the effect of exposure $(5,8 \mu \mathrm{g} / \mathrm{L})$ and shows similar characteristics with the other studies performed previously. In some studies performed in USA in recent years, it has been proposed that the mercury content of vaccines (thimerosal) is related with neurodevelopmental diseases including mainly autism (23). However, a similar increase in the prevalence of autism has been shown similar to the worldwide increase in many large-scale studies performed 
in many European countries which removed thimerosal from the vaccines before USA $(24,25,26)$. The total mercury content of the vaccines used in the vaccination schedule of our country is much more lower than the acceptable threshold levels. Only hepatitis B vaccine contains mercury among the vaccines which have been administered since 2008. In children who have been vaccinated fully, the total mercury content received is $137.5 \mu \mathrm{g}$ before 2008 and 37.5 $\mu \mathrm{g}$ after 2008 . Additionally, the mercury inside the vaccine is ethyl mercury and its half-life is much shorter (seven days) than the half-life of the methyl mercury received from nature. In our study, the mean blood mercury level was found to be substantially lower than the toxic value and no difference was found between the age groups in terms of the distribution of blood mercury levels. This shows that children are not affected by exposure to vaccines or other sources of mercury. Again, no difference was found between the blood lead levels of the patients with autism and healthy children in our study. Although contradictory results have been obtained in studies which examine the relation between lead and autism in the literature, determinations in favour of the opinion that there is no relation are gaining weight $(27,28)$. In the study performed by Yorbık et al. (29), the hair lead levels in autistic children were not found to be different compared to normal children.

Some investigators propose that even low amounts of lead exposure (below $10 \mu \mathrm{g} / \mathrm{dL}$ ) will cause attention deficit and hyperactivity in healthy children $(30,31)$. In the study performed by Wang et al. (32) in China which is the largest-scale study performed until today, it was found that the blood lead level in patients with ADHD $(8.77 \mu \mathrm{g} / \mathrm{dL})$ was significantly higher compared to healthy children (5.76 $\mu \mathrm{g} / \mathrm{dL})$. In China, environmental pollution has extreme dimensions. The lead level is above $10 \mu \mathrm{g} / \mathrm{dL}$ in of healthy children. Altough different results have been obtained in various studies examining the relation between mercury and ADHD, the blood mercury levels in the subjects in these studies have been found to be below the toxic level $(5,33,34)$. In our study, no significant difference was found between the ADHD group and the healthy control group in terms of blood lead and mercury levels.

Studies have shown that the cognitive functions of children are affected negatively even at levels below the threshold blood values determined for lead and mercury. In a study in which the blood lead level was followed up with regular intervals from the newborn period, it was found that the intelligence level score was 4.9 lower in children with a blood lead level between 5 and $9.9 \mu \mathrm{g} / \mathrm{dL}$ compared to the children with a blood lead level below 0-5 $\mu \mathrm{g} / \mathrm{dL}$. In another study, it was reported that with every $1 \mathrm{ug} / \mathrm{dL}$ increase in the blood lead level the intelligence level was reduced by a score of $1.37(4,35)$. In our study, no significant difference was found between children with MMR and healthy children in terms of blood lead levels. We think the finding that there was no significant relation between motor mental retardation and lead and mercury levels may be explained by the fact that our patients had severe-moderate MMR and unknown risk factors other than heavy metals might be involved.

In our study, no significant difference was found between the epilepsy group and control group in terms of blood lead and mercury levels. No publication examining the relation between epilepsy and lead or mercury has been found in the literature. Studies mostly include epilepsy cases caused by high doses of lead or mercury intoxications $(36,37)$.

There are some limitations of our study. The patient and control groups did not have efficient numbers to strongly examine if there was a relation between neurodevelopmental diseases and heavy metals. However, the sample size is large enough to make an accurate statistical assessment. All factors which might have led to potential heavy metal exposure in the environment of children could not be examined. However, the house and region of residence, water and radiator pipes, line of business of the family members who worked were questioned in the history, no significant potential risk factors could be found and factors including vaccinations and food consumption were addressed.

Conclusively, our study showed that the blood lead and mercury levels of children with neurodevelopmental disease were not different compared to healthy children. Since the sample sizes of the groups were small, it is not possible to obtain a cause-effect relation. Large-scale prospective studies examining the relation between morbidity and heavy metals are needed depending on the changing environmental conditions and nutritional status. In addition, the blood threshold levels specified for lead and mercury are not definite results which are accepted internationally; they are shown as source values. It should be considered that long-term heavy metal exposure below these levels may trigger neurodevelopmental disorders especially in early childhood. Therefore, prevention of environmental pollution caused by heavy metals gains great importance in terms of public health.

\section{Conflict of interest: None declared.}

\section{References}

1. Odding E, Roebroeck ME, Stam HJ. The epidemiology of cerebral palsy: incidence, impairments and risk factors. Disabil Rehabil 2006;28: 83-191.

2. Theoharides TC, Kempuraj D, Redwood L. Autism: an emerging "neuroimmune disorder" in search of therapy. Expert Opin Pharmacother 2009;10: 2127-2143.

3. Davidson PW, Myers GJ, Weiss B. Mercury exposure and child development outcomes. Pediatrics 2004:113; 1023-1029.

4. Canfield RL, Henderson CR, Cory-Slechta DA, Cox C, Jusko TA, Lanphear BP. Intellectual impairment in children with blood lead concentrations below $10 \mu \mathrm{g}$ per deciliter. N Engl J Med 2003; 348: 1517-1526. 
5. Cheuk DK, Wong V. Attention-deficit hyperactivity disorder and blood mercury level:A case-control study in Chinese children. Neuropediatrics 2006; 37: 234-240.

6. Nigg JT, Nikolas M, Knottnerus GM, Cavanagh K, Friderici K. Confirmation and extension of association of blood lead with attention-deficit/hyperactivity disorder (ADHD) and ADHD symptom domains at population-typical exposure. Levels J Child Psychol Psychiatry 2010;51: 58-65.

7. Bradstreet J, Geier DA, Kartzinel JJ, Adams JB, Geier MR. Casecontrol study of mercury burden in children with autistic spectrum disorders. J Am Phys Surg 2003;8:76-79.

8. Bernard SL, Enayati A, Binstock T, Roger H, Redwood L, McGinnis W. Autism: A unique type of mercury poisoning. Cranford, $\mathrm{NJ}$ : ARC Research, 2000. https://legacy.autism.com/triggers/vaccine/ mercurylong.htm . Erişim tarihi: 09.02.2013

9. American Psychiatric Association. Task Force on DSM-IV. Diagnostic and Statistical Manual of Mental Disorders: DSMIV-TR. 4th ed. Washington: American Psychiatric Association, 2000:1-943.

10. Cornelis R, Nordberg M. General chemistry, sampling, analytical methods, and speciation, atomic absorption spectrometry. In: Nordberg GF, Fowler BA, Nordberg M, Friberg L,(eds). Handbook on the Toxicology of Metals 3rd ed. Academic Pres, 2005; 2: 4447.

11. US Centers for Disease Control. Preventing lead poisoning in young children. Atlanta, GA, 1991. http://www.cdc.gov/nceh/lead/ Publications/books/plpyc/contents.htm. Erişim tarihi: 12.01.2013.

12. Centers for Disease Control and Prevention (CDC). Blood mercury levels in young children and childbearing-aged women in United States, 1999-2002. Morb Mortal Wkly Rep 2004; 53: 1018-1020.

13. Ball IK, Ball R, Pratt RD. An assessment of thimerosal use in childhood vaccines. Pediatrics 2001;107: 1147-1154.

14. Vural N, Güvendik G. Ankara'da yaşayan çocuklarda kurşun absorpsiyonunun çevre kirliliği ile ilgisinin araştırılması. Ulusal Çevre Sempozyumu. Adana, 1994.

15. Kısmet E, Karataş M, Demirkaya E, ve ark. Ankara'da farklı bölgelerde yaşayan değişik yaş grubu çocuklarda kan kurşun düzeyleri. Gülhane Tıp Dergisi 2004; 46: 3337.

16. Göker Ş, Aydın A. İstanbul'un çeşitli semtlerinde oturan çocuklarda kan kurşun düzeyleri ve bu düzeylere etki eden risk faktörleri. Türk Pediatri Arşivi 2000; 35: 15-23.

17. Böttjer NK, Kaypmaz A. İlkokul çocuklarında kan kurşun düzeyi ve risk faktörleri ve subjektif okul başarı durumu ilişkisi. iÜ CTF Uzmanlık tezi. İstanbul, 2008.

18. Centers for Disease Control and Prevention (CDC). Blood lead levels in young children-United States and selected states, 19961999. MMWR Morb Mortal Wkly Rep 2000 ;49: 1133-1137.

19. Doğan-Sağlamtimur $\mathrm{N}$, Kumbur $\mathrm{H}$. Metals $(\mathrm{Hg}, \mathrm{Pb}, \mathrm{Cu}$ and $\mathrm{Zn})$ bioaccumulation in sediment, fish and human scalp hair: a case study from the city of Mersin along the southern coast of Turkey. Biol Trace Elem Res 2010; 136: 55-70.

20. Ulukapi I, Cengiz S, Sandalli N. Effect of mercury from dental amalgams on mercury concentration in urine. J Nihon Univ Sch Dent 1994; 36: 266-268.

21. Wong SL, Ellen JD. Lead, mercury and cadmium levels in Canadians. Statistics Canada. Health Reports, 2008;19:4.

22. Ip P, Wong V, Ho M, Lee J, Wong W. Environmental mercury exposure in children: South China's experience. Pediatr Int 2004; 46: 715-721.
23. Geier DA, Geier MR. A comparative evaluation of the effects of MMR immunization and mercury doses from thimerosalcontaining childhood vaccines on the population prevalence of autism. Med Sci Monit 2004;10: 33-39.

24. Stehr-Green P, Tull P, Stellfeld M, Mortenson PB, Simpson D. Autism and thimerosal-containing vaccines: lack of consistent evidence for an association. Am J Prev Med 2003; 25: 101-106.

25. Madsen KM, Lauritsen MB, Pedersen CB, Thorsen P, Plesner AM, Andersen PH, Mortensen PB. Thimerosal and the occurrence of autism: negative ecological evidence from Danish populationbased data. Pediatrics 2003;112: 604-606.

26. Heron J, Golding J. Thimerosal exposure in infants and developmental disorders: a prospective cohort study in the United Kingdom does not support a causal association. Pediatrics 2004; 114: 577-583.

27. Clark B, Vandermeer B, Simonetti A, Buka I. Is lead a concern in Canadian autistic children? Paediatr Child Health 2010; 15: 1722.

28. Majewska MD, Urbanowicz E, Rok-Bujko P, Namyslowska I. Age-dependent lower or higher levels of hair mercury in autistic children than in healthy controls. Acta Neurobiol Exp 2010:70; 196-208.

29. Yorbık Ö, Dilaver B, Cansever A, Akay C, Sayal A, Söhmen T. Otistik çocuklarda saç kurşun düzeylerinin araştırılması. Klinik Psikiyatri Dergisi 2003; 6: 213-216.

30. Needleman HL, Riess JA, Tobin MJ, Biesecker GE, Greenhouse JB. Bone lead levels and delinquent behavior. JAMA 1996; 275: 1727-1728.

31. Roy A, Bellinger D, Hu H, Schwartz J, Ettinger AS, Wright RO, Bouchard M, Palaniappan K, Balakrishnan K. Lead exposure and behavior among young children in Chennai, India. Environ Health Perspect 2009; 10: 1607-1611.

32. Wang HL, Chen XT, Yang B, Ma FL, Wang S, Tang ML, Hao MG, Ruan DY. Case-control study of blood lead levels and attention deficit hyperactivity disorders in Chinese children. Environ Health Perspect 2008;116:1401-1406.

33. Nicolescu R, Petcu C, Cordeanu A, Fabritius K, Schlumpf M, Krebs R, Krämer U, Winneke G. Environmental exposure to lead, but not other neurotoxic metals, relates to core elements of ADHD in Romanian children: performance and questionnaire data. Environ Res 2010; 110: 476-483.

34. Ha M, Kwon HJ, Lim MH, Jee YK, Hong YC, Leem JH, Sakong J, Bae JM, Hong SJ, Roh YM, Jo SJ. Low blood levels of lead and mercury and symptoms of attention deficit hyperactivity in children: a report of the children's health and environment research (CHEER). Neurotoxicol 2009; 30: 31-36.

35. Mazumdar M, Bellinger D, Gregas M, Abanilla M, Bacic J, Needleman $H$. Low-level environmental lead exposure in childhood and adult intellectual function: a follow-up study. Environmental Health 2011; 10: 24-31.

36. Ragothaman M, Kulkarni G, Ashraf VV, Pal PK, Chickabasavaiah Y, Shankar SK, Govindappa SS, Satishchandra P, Muthane UB. Elemental mercury poisoning probably causes cortical myoclonus. Mov Disord 2007; 22: 1964-1968.

37. Lockitch G, Berry B, Roland E, Wadsworth L, Kaikov Y, Mirhady F. Seizures in a 10-week-old infant: lead poisoning from an unexpected source. CMAJ 1991; 145: 1465-1468. 